DOI: $\underline{\text { https://doi.org/10.31933/jemsi.v2i5 }}$

Received: 28 April 2021, Revised: 15 Mei 2021, Publish: 8 Juli 2021

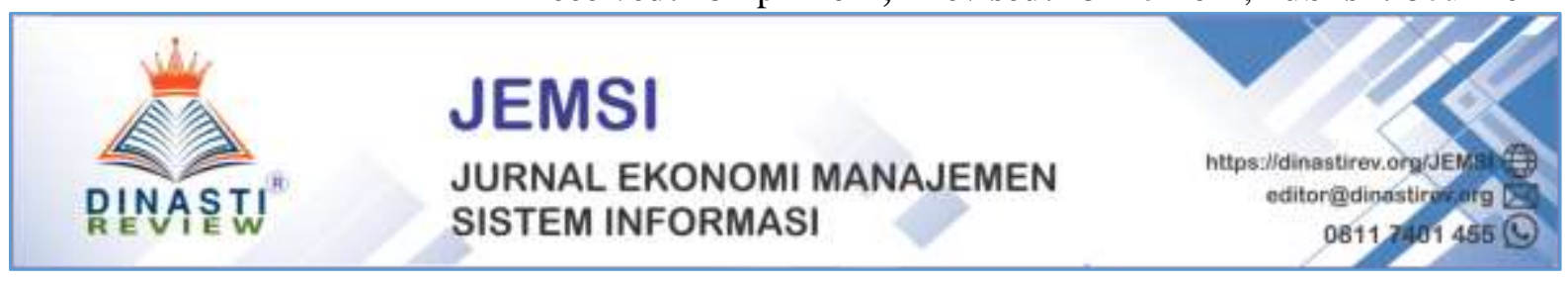

\title{
DETERMINASI INDEKS HARGA SAHAM GABUNGAN: ANALISIS PENGARUH BI RATE, KURS RUPIAH DAN TINGKAT INFLASI (LITERATURE REVIEW MANAJEMEN KEUANGAN)
}

\author{
Lida Hawiwika ${ }^{1}$ \\ ${ }^{1)}$ Mahasiswa Program Magister Manajemen, Universitas Mercu Buana Jakarta, \\ lida99hawiwika@gmail.com
}

\section{Corresponding Author: Lida Hawiwika ${ }^{1}$}

Abstract: Riset terdahulu atau riset yang relevan sangat penting dalam suatu riset atau artikel ilmiah. Riset terdahulu atau riset yang relevan berfungsi untuk memperkuat teori dan fenomena hubungan atau pengaruh antar variabel. Artikel ini mereview Determinasi Indeks Harga Saham Gabungan: Analisis BI Rate, Kurs Rupiah dan Tingkat Inflasi (Literature Review Manajemen Keuangan). Hasil dari library research ini adalah bahwa: 1) BI Rate berpengaruh terhadap Indeks Harga Saham Gabungan; 2) Kurs Rupiah berpengaruh terhadap Indeks Harga Saham Gabungan; 3) Tingkat Inflasi berpengaruh terhadap Indeks Harga Saham Gabungan; 4) BI Rate, Kurs Rupiah, dan Tingkat Inflasi berpengaruh simultan terhadap Indeks Harga Saham Gabungan.

Keyword: Kurs Rupiah, BI Rate, Tingkat Inflasi, Indeks Harga Saham Gabungan.

\section{PENDAHULUAN}

\section{Latar Belakang Masalah}

Setiap mahasiswa baik Strata 1, Strata 2 dan Strata 3, di wajibkan untuk melakukan riset dalam bentuk skripsi, tesis dan disertasi. Begitu juga bagi dosen, peneliti dan tenaga fungsional lainya aktif melakukan riset dan membuat artikel ilmiah untuk di publikasi pada jurnal-jurnal ilmiah.

Berdasarkan pengalaman empirik banyak mahasiswa dan dosen muda juga peneliti lainnya, kesulitan untuk mencari artikel pendukung dalam riset sebagai penelitian terdahulu atau sebagai penelitian yang relevan. Artikel sebagai peneliti yang relevan di perlukan untuk memperkuat teori yang di teliti, untuk melihat hubungan antar variabel dan membangun hipotesis, juga sangat diperlukan pada bagian pembahasan hasil penelitian.

Artikel ini membahas pengaruh BI Rate, Kurs Rupiah, Tingkat Inflasi terhadap indeks harga saham gabungan dan hubungan sebab akibat indeks harga saham gabungan dengan BI Rate, Kurs Rupiah, Tingkat Inflasi, (Suatu Studi Literatur Manajemen Keuangan). Tentu 
tidak semua variabel saling mempengaruhi dan memiliki hubungan sebab akibat, ini hanya sebagian kecil saja yang akan di kaji dan di review.

Secara rinci tujuan dari penulisan "Literature Review Paper" ini adalah mengetahui pengaruh dan hubungan sebab akibat antara variabel exogen BI Rate, Kurs Rupiah dan Tingkat Inflasi terhadap variabel endogen indeks harga saham gabungan.

1) BI Rate berpengaruh terhadap Indeks Harga Saham Gabungan

2) Kurs Rupiah berpengaruh terhadap Indeks Harga Saham Gabungan

3) Tingkat Inflasi berpengaruh terhadap Indeks Harga Saham

4) BI Rate, Kurs Rupiah, dan Tingkat Inflasi berpengaruh simultan terhadap Indeks Harga Saham Gabungan

\section{KAJIAN TEORI (dari buku+Artikel)}

\section{Indeks Harga Saham Gabungan}

Indeks harga saham merupakan informasi historis yang dijadikan tolak ukur kinerja gabungan seluruh harga saham yang tercatat di bursa efek (Sunariyah, 2006:142). Darmadji (2006:167) berpendapat bahwa suatu indikator yang dapat menunjukan pergerakan harga saham adalah indeks harga saham. Menurut Jogiyanto (206:57) Indeks Harga Saham Gabungan (IHSG) merupakan suatu indikator yang menunjukan pergerakan suatu saham, berfungsi sebagai indikator trend pasar yang berarti pergerakan dari indeks menggambarkan kondisi pasar pada saat sedang aktif atau lesu.

Anorga dan Pakarti (2006:100), menyatakan secara sederhana "indeks harga saham adalah suatu peristiwa yang digunakan untuk membandingkan suatu peristiwa dibandingkan dengan peristiwa lainnya". Pendapat tersebut bermakna bahwa ditujukan untuk membandingkan perubahan harga saham dari waktu ke waktu, apakah mengalami peningkatan ataupun penurunan. Kondisi yang tidak disukai oleh investor adalah ketika indeks harga saham lesu atau mengalami penurunan karena hal tersebut dapat menurunkan keuntungan mereka (Tesa,2012). Pergerakan Indeks Harga Saham Gabungan (IHSG) dipengaruhi oleh beragam faktor, diantaranya kondisi ekonomi makro dan ekonomi global. Kondisi ekonomi makro yang dapat mempengaruhi pegerakan Indeks Harga Saham Gabungan (IHSG) yaitu adanya tingkat inflasi dan nilai tukar.

Indeks Harga Saham Gabungan sudah banyak di teliti oleh peneliti sebelumnya di antaranya oleh (Rochmaniza \& Masbar, 2016), (Miyanti \& Wiagusti, 2018), (Hendayanti \& Nurhayati, 2018), (Natsir, Yusbardini, \& Bangun, 2019), (Juliodinata, Ahmar, \& Tiro, 2019), (Desvina \& Lubis, 2019), (Anggriana \& Paramita, 2020), (Situngkir, 2019), (Wikayanti, Aini, \& Fitriyani, 2020)

\section{BI Rate}

Bank Indonesia (2018) BI Rate menyampaikan suku bunga yang mencerminkan sikap atau stance kebijakan moneter yang ditetapkan oleh Bank Indonesia dan diumumkan kepada publik. BI Rate diumumkan oleh Dewan Gubernur Bank Indonesia setiap Rapat Dewan Gubernur (RDG) bulanan dan diimplementasikan pada operasi moneter yang dilakukan Bank Indonesia melalui pengelolaan liquiditas (liquidity management) di pasar uang untuk mencapai sasaran operasioanal kebijakan moneter. Sasaran operasional kebijakan moneter dicerminkan pada perkembangan suku bunga pasar uang antar Bank Overnight. Pergerakan di suku bunga deposito, dan pada giliranya suku bunga kredit perbankan. 
Bank Indonesia menerapkan kerangka kebijakan moneter melalui penerapan suku bunga. Sejak tahun 2005, Bank Indonesia menerapkan kerangka kebijakan moneter dengan inflasi sebagai sasaran utama kebijakan moneter (Inflation Targeting Framework/ITF) dengan menganut sistem nilai tukar yang mengambang (free floating) untuk mencapai kestabilan nilai rupiah (Bank Indonesia,2018). Bank Indonesia umumnya menaikan BI Rate apabila inflasi ke depan diperkirakan melampaui sasaran yang telah ditetapkan, sebaliknya Bank Indonesia akan menurunkan BI Rate apabila inflasi ke depan diperkirakan berada di bawah sasaran yang ditetapkan.

Menurut Amin (2012), suku bunga merupakan tingkat bunga yang telah diputuskan oleh Bank Indonesia sekaligus menjadi acuan untuk tingkat bunga standard oleh bank pemerintah dan bank swasta. Penelitian ini perhitungannya memakai nilai BI Rate asli.

Penelitian tentang BI Rate telah banyak dikaji oleh penelitian sebelumnya seperti penelitian yang dikembangkan oleh (Sartika, 2017), (Miyanti \& Wiagusti, 2018), (Anggriana \& Paramita, 2020), (Desvina \& Lubis, 2019).

\section{Kurs Rupiah}

Miskhin (2011:136) menyampaikan bahwa kurs merupakan harga dari mata uang suatu negara dalam harga mata uang dengan negara lainnya. Kurs penting karena kurs valas mempengaruhi harga barang-barang yang diproduksi di dalam negeri yang dijual di luar negeri dan biaya dari barang-barang luar negeri yang dibeli di negara domestik. Mishkin (2011:110) mengatakan bahwa ketika mata uang suatu negara terapresiasi (nilainya naik secara relative terhadap mata uang lainnya), barang yang dihasilkan oleh negara tersebut di luar negeri menjadi lebih mahal dan barang-barang luar negeri di negara tersebut menjadi lebih murah (asumsi harga domestik konstan di kedua negara). Sebaliknya, ketika mata uang negara terdepresiasi, barang-barang negara tersebut yang di luar negeri menjadi lebih murah dan barang-barang luar negeri di negara tersebut menjadi lebih mahal.

Kurs Rupiah terbagi menjadi dua yaitu, kurs nominal dan kurs rill. Kurs nominal (nominal exchange rate) adalah nilai yang digunakan seseorang saat menukar mata uang suatu negara dengan mata uang negara lain. Sedangkan nilai rill (real exchange) adalah nilai yang digunakan seseorang saat menukar barang dan jasa dari suatu negara dengan barang dan jasa dari negara lain.

Penelitian tentang Kurs Rupiah telah banyak dikaji oleh penelitian sebelumnya seperti penelitian yang dikembangkan oleh (Sartika, 2017), (Miyanti \& Wiagusti, 2018), (Anggriana \& Paramita, 2020), (Desvina \& Lubis, 2019).

\section{Tingkat Inflasi}

Inflasi merupakan tingkat kenaikan harga secara keseluruhan. Menurut Halim (2009:87), inflasi adalah kecenderungan kenaikan harga barang- barang dan jasa termasuk faktor-faktor produksi secara umum dan terus menerus. Harga yang dimaksud dalam pengertian inflasi ini bukan harga yang ditetapkan oleh pemerintah, tetapi harga yang terjadi di pasar antara pihak-pihak yang bebas. Kenaikan harga terjadi karena inflasi, bukan karena faktor teknologi, sifat-sifat barang, dan pengaruh musim (misalnya hari raya).

Arifin (2012:12) menyatakan bahwa pengertian inflasi yang paling sederhana adalah 
kenaikan harga barang-barang secara umum atau penurunan daya beli dari sebuah satuan mata uang. Jika harga satu macam barang naik sedangkan yang lainnya tetap maka belum dapat dikatakan telah terjadi jika harga barang-barang kebutuhan pokok seperti beras, gula, minyak, dan sebagainya bergerak naik secara serentak dan menyeluruh di semua tempat. Kenaikan harga produk tersebut tentu akan membuat harga barang-barang lainya juga naik. Pada saat itulah daya beli dari uang kita menjadi turun dan terjadilah inflasi.

Penelitian tentang inflasi telah banyak dikaji oleh penelitian sebelumnya seperti penelitian yang dikembangkan oleh (Sartika, 2017), (Miyanti \& Wiagusti, 2018), (Anggriana \& Paramita, 2020), (Hendayanti \& Nurhayati, 2018), (Nurhidayati, 2018).

\section{METODE PENULISAN}

Metode penulisan artikel ilmiah ini adalah dengan metode kualitatif dan studi literature atau Library Research. Mengkaji Buku-buku literature sesuai dengan teori yang di bahas khusunya di lingkup Manajemen Keuangan. Disamping itu menganalisis artikel-artikel ilmiah yang bereputasi dan juga artikel ilmiah dari jurnal yang belum bereputasi. Semua artikel ilmiah yang di citasi bersumber dari Mendeley dan Scholar Google.

Dalam penelitian kualitatif, kajian pustaka harus digunakan secara konsisten dengan asumsi-asumsi metodologis. Artinya harus digunakan secara induktif sehingga tidak mengarahkan pertanyaan-pertanyaan yang diajukan oleh peneliti. Salah satu alasan utama untuk melakukan penelitian kualitatif yaitu bahwa penelitian tersebut bersifat eksploratif, (Ali \& Limakrisna, 2013).

Selanjutnya dibahas secara mendalam pada bagian yang berjudul" Pustaka Terkait" (Related Literature) atau Kajian pustaka( "Review of Literature"), sebagai dasar perumusan hipotesis dan selanjutnya akan menjadi dasar untuk melakukan perbandingan dengan hasil atau temuan-temuan yang terungkap dalam penelitian, (Ali \& Limakrisna, 2013).

\section{PEMBAHASAN}

\section{Pengaruh BI Rate terhadap Indeks Harga Saham Gabungan}

Suku bunga yang naik akan memengaruhi secara negatif atas pasar modal. Pada Signalling Theory menurut Jogiyanto (2000:392) dalam penelitian Maulinda (2018), menjelaskan bahwa informasi yang dipublikasikan perusahaan sebagai pengumuman akan memberikan sinyal bagi para investor untuk mengambil keputusan dalam berinvestasi. Jika pengumuman yang dipublikasikan tersebut positif, maka diharapkan pasar akan merespon positif pada waktu atau setelah pengumuman tersebut diterima oleh pasar. Jika suku bunga SBI meningkat, maka investor akan mendapatkan hasil yang lebih besar atas suku bunga deposito yang ditanamkan sehingga investor akan cenderung untuk mendepositokan modalnya dibandingkan menginvestasikan dalam saham (Sartika 2017). Penelitian yang dilakukan oleh Gumilang, Hidayat, \& Endang NP (2014), Robiyanto (2018) dan Witjaksono (2010) menunjukkan adanya pengaruh signifikan negatif yang artinya saat suku bunga mengalami kenaikan maka harga saham akan turun dan sebaiknya.

\section{Pengaruh Kurs Rupiah terhadap Indeks Harga Saham Gabungan}

Menurut Darmadji (2006) dalam penelitian Sartika (2017), nilai tukar mata uang atau sering disebut kurs merupakan harga mata uang terhadap mata uang lainnya. Berdasarkan 
signalling theory pergerakan harga saham bergantung dari informasi yang diterima oleh investor. Informasi tersebut bisa berupa good news atau bad news. Penentuan nilai kurs mata uang suatu negara dengan mata uang negara lain ditentukan sebagaimana halnya barang yaitu oleh permintaan dan penawaran mata uang yang bersangkutan. Hukum ini juga berlaku pada kurs rupiah, jika permintaan akan rupiah lebih besar daripada penawarannya, maka kurs rupiah akan terapresiasi, demikian pula sebaliknya. Ketika mata uang rupiah terdepresiasi, maka mengakibatkan naiknya biaya bahan baku, sehingga menyebabkan kenaikan biaya produksi dan akan berpengaruh pada penurunan tingkat keuntungan perusahaan. Hal ini akan mendorong investor untuk menjual saham-saham yang dimilikinya. Apabila banyak investor yang melakukan hal tersebut, tentu akan mendorong penurunan indeks harga saham gabungan (Witjaksono 2010). Hasil riset oleh Harsono \& Wonokinasih, (2018); Husnul et al., (2017); Jayanti (2014); Lestari et al., (2016); Prawirosaputro \& Hapsari (2017) bahwa adanya pengaruh nilai tukar (kurs) menandakan bahwa semakin tinggi nilai tukar (kurs) dapat mengakibatkan penurunan terhadap indeks harga saham gabungan.

\section{Pengaruh Kurs Tengah BI terhadap Indeks Harga Saham Gabungan}

Inflasi merupakan faktor ekonomi yang dapat memberikan pengaruh pada pergerakan Indeks Harga Saham Gabungan. Menurut Bank Indonesia (2019), inflasi diartikan sebagai naiknya harga secara umum dan terus menerus dalam jangka waktu tertentu. Tandelilin (2010:342) menyatakan bahwa inflasi adalah harga produk-produk di masyarakat yang meningkat secara menyeluruh. Jadi apabila inflasi meningkat drastis maka akan memengaruhi harga sama suatu negara, karena perusahaan akan mengalami kebangkrutan atas biaya bahan baku yang sangat tinggi. Berdasarkan signalling theory pergerakan harga saham bergantung dari informasi yang diterima oleh investor. Informasi tersebut bisa berupa good news atau bad news. Inflasi dapat dikatakan sebagai informasi ganda karena inflasi dapat menyebabkan informasi bersifat good news atau bad news. Ketika suatu kondisi perekonomian sedang krisis, maka inflasi akan naik sehingga kurs rupiah terhadap dollar melemah karena biaya akan konsumsi lebih besar dari sebelumnya sehingga permintaan akan dollar semakin tinggi dan membuat melemahnya nilai tukar rupiah. Hasil riset Nofiatin (2013) dan Sudarsana \& Candraningrat (2014) menunjukkan bahwa inflasi berpengaruh negatif terhadap IHSG karena apabila inflasi meingkat, maka IHSG semakin menurun.

\section{BI Rate, Kurs Rupiah, dan Tingkat Inflasi berpengaruh simultan terhadap Indeks Harga Saham Gabungan}

Pada kondisi ekonomi tertentu, menimbulkan beragam perubahan aktivitas seperti permintaan komoditas dan kebijakan yang dikeluarkan dengan tujuan untuk menstabilkan keadaan, sehingga berdampak pada sikap investor dalam mengalokasikan dana investasinya. Disampaikan oleh Dimitrova (2005) ada beberapa alasan penting sehingga perlu membangun hubungan antara saham dan nilai tukar, yaitu:

1) Berkaitan dengan kebijakan moneter dan fiscal

2) Memprediksi jalur nilai tukar

3) Mengelola mata uang sebagai aset dalam portofolio investasi

4) Meramalkan krisis

Alasan tersebut dapat menjelaskan hubungan antara IHSG dengan kurs. Saat rupiah terdepresiasi oleh US\$, maka menandakan bahwa kondisi ekonomi Indonesia sedang melemah. Hal tersebut berakibat pada perilaku investor yang menjual sahamnya atau menahan hingga mengalihkan dana investasi dengan tujuan untuk meminimalisir risiko. 
Seperti yang disampaikan oleh Joesof \& Rizal (2007), dimana aksi menjual saham akan berdampak pada turunnya nilai IHSG.

BI Rate, Kurs rupiah dan inflasi digunakan sebelum melakukan investasi di BEI. Informasi tersebut menjadi sala satu pertimbangan investor sebelum membeli saham untuk memperkirakan harga saham di masa depan. Investor melihat informasi suku bunga sebelum mengambil keputusan menjual atau membeli saham di BEI berkaitan dengan teori Klasik dalam Nopirin (2012:167) menyatakan bahwa "semakin tinggi tingkat bunga, maka semakin tinggi keinginan masyarakat untuk menabung, namun semakin rendah keinginan masyarakat untuk melakukan investasi". Oleh karena itu investor termotivasi menabung pada tingkat bunga yang tinggi karena mengorbankan atau mengurangi pengeluaran untuk konsumsi guna menambah tabungan.

\section{Conceptual Framework}

Berdasarkan rumusan masalah penulisan artikel ini dan kajian studi literature review baik dari buku dan artikel yang relevan, maka di perolah rerangka artikel ini seperti di bawah ini.

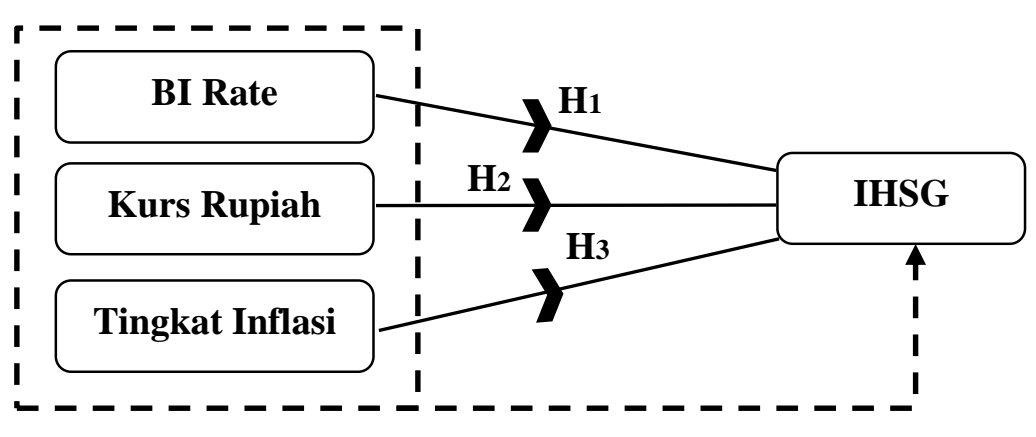

\section{Gambar 1: Rerangka Berfikir}

Indeks Harga Saham Gabungan berpengaruh dan berpotensi memiliki hubungan sebab akibat terhadap BI Rate, Kurs Rupiah dan Tingkat Inflasi.

Selain dari variabel Indeks Harga Saham Gabungan yang mempengaruhi BI rate, kurs rupiah dan tingkat inflasi masih banyak variabel lain yang mempengaruhinya, di antaranya adalah variabel:

1) Harga Emas (x4): (Basit, 2020), (Rochmaniza \& Masbar, 2016), (Fadah, Kristanto, \& Puspitasari, 2017)

2) Harga Minyak (x5) : (Miyanti \& Wiagusti, 2018), (Rochmaniza \& Masbar, 2016) \& (Fadah, Kristanto, \& Puspitasari, 2017)

3) Indeks Dow Jones (x6): (Natsir, Yusbardini, \& Bangun, 2019), (Desfiandi, Desfiandi, \& Ali, 2017), (Giannarakis, Garefalakis, Lemonakis, \& Sariannidis, 2017).

\section{KESIMPULAN DAN SARAN}

\section{Kesimpulan}

Hypothesis testing research adalah penelitian yang bertujuan untuk mengembangkan hipotesis dan mengujinya secara empiris atas suatu permasalahan tertentu (Ali \& Limakrisna, 
2013). Berdasarkan rumusan artikel, hasil dan pembahasan, maka dapat di di rumuskan hipotesis untuk riset selanjutnya:

1. BI Rate berpengaruh terhadap Indeks Harga Saham Gabungan.

2. Kurs Rupiah berpengaruh terhadap Indeks Harga Saham Gabungan.

3. Tingkat Inflasi berpengaruh terhadap Indeks Harga Saham Gabungan.

4. BI Rate, Kurs Rupiah, dan Tingkat Inflasi berpengaruh simultan terhadap Indeks Harga Saham Gabungan.

\section{Saran}

Berdasarkan Kesimpulan di atas, maka saran pada artikel ini adalah bahwa masih banyak variable lain yang mempengaruhi BI rate, kurs rupiah dan tingkat inflasi, selain dari Indeks Harga Saham Gabungan, oleh karena itu masih di perlukan kajian yang lebih lanjut untuk mencari variable - variabel lain yang di teliti pada arikel ini.

\section{DAFTAR PUSTAKA}

Ali, H., \& Limakrisna, N. (2013). Metodologi Penelitian (Petunjuk Praktis untuk Pemecahan Masalah Bisnis, Penyusunan Skripsi, Tesis, dan Disertasi). Deeppublish: Yogyakarta

S, Pardomuan. (2018). Coorporate Financial Management. Edisi 1. Bogor.

Rochmaniza, R. \& Masbar, R. (2016). Analisis Variabel Maktoekonomi dan IHSG Indonesia, Jurnal Ilmiah Mahasiswa, 1 (2), 358-368.

Fadah, I., Kristanto, D. \& Puspitasari, N. (2017). Harga Minyak Bumi dan Emas Dunia Sebagai Penentu Pergerakan Indeks Sektoral di BEI Periode 2011-2015, Jurnal Ekonomi dan Keuangan, 1 (4), 2548-5024.

Miyanti, G.A.D.A. \& Wiagustini, L.P. (2018). Pengaruh Suku Binga The Fed, Harga Minyak dan Inflasi Terhadap Indeks Harga Saham Gabungan (IHSG) di Bursa Efek Indonesia, Jurnal Ekonomi dan Bisnis, 7 (5), 2337-3067.

Hendayanti, N.P.N. \& Nurhidayati, M. (2018). Analisis Hubungan antara Inflasi, Nilai Tukar dan Indeks Harga Saham Gabungan dengan Pendekatan VECM dan VECMX, Jurnal Ekonomi Syariah, 1 (2), 2622-6936.

Natsir, K., Yusbardini \& Bangun, N. (2019). Analisis Kausalitas antara IHSG, Indeks Dow Jones Industrial Average dan Nilai Tukar Rupiah/US\$, Jurnal Muara Ilmu Ekonomi dan Bisnis, 3 (2), 2579-6224.

Juliodinata, A.I., Ahmar, A.S. \& Tiro, M.A. (2019). Metode Vector Autoregressive dalam Menganalisis Pengaruh Kurs Mata Uang, Inflasi dan Suku Bunga Terhadap Indeks Harga Saham Gabungan, Journal of Statistic and Its Application on Teaching and Research, 1 (2), 2684-7590.

Desvina, A.P. \& Lubis, P.S. (2019). Pendekatan VECM untuk Menganalisis Hubungan IHSG, BI Rate, Kurs (USD/IDR), dan Jumlah Uang yang Beredar (M2), Jurnal Sains Matematika dan Statistika, 5 (1), 2460-4542. 
Basit, A. (2020). Pengaruh Harga Emas dan Minyak Dunia Terhadap Indeks Harga Saham Gabungan (IHSG) Periode 2016-2019, Jurnal Manajemen Bisnis Islam, 1 (2), 2715$825 \mathrm{X}$.

Situngkir, T.L. (2019). Pengaruh Jangka Pendek dan Jangka Panjang Variabel Suku Bunga Terhadap Indeks Harga Saham Gabungan (IHSG) dengan Pendekatan Error Correction Model, Jurnal Ilmiah Nasional Bidang Ilmu Teknik, 7 (2), 2337-3636.

Wikayanti, N.L.P.D., Aini, Q. \& Fitriyani, N. (2020). Pengaruh Kurs Dolar Amerika Serikat, Inflasi, dan Tingkat Suku Bunga Terhadap Indeks Harga Saham Gabungan dengan Model Vector Error Correction, Eigen Mathematics Journal, 3 (1), 2615-3270.

Desfiandi, A., Desfiandi, A. \& Ali, H. (2017). Composite IHSG Macro factor in investment in stock, International Journal of Economics and Financial Issues, 7 (3), 534-536.

Sydogan, B., Tunc, G. \& Yelkenci, T. (2017). The Impact of oil price volatility on net-oil exporter and importer countries stock markets, Eurasia Business and Economics Society, Eurasian Econ Rev.

Wirama, D.G., Wiksuana, I.G.B., Mohn-Sanusi, Z. \& Kazemian, S. (2017). Price Manipulation by Dissemination of Rumors: Evidence from the Indonesian Stock Market, International Journal of Economics and Financial Issues, 7 (1), 429-434.

Pitoska, P., Katarachia, A., Giannarakis, G. \& Tsilikas, C. (2017). An Analysis of Determinants Affecting the Returns of Dow Jones Sustainability Index United States, International Journal of Economics and Financial Issues, 7 (3), 113-118.

Giannarakis, G., Garefalakis, A., Lemonakis, C. \& Sariannidis, N. (2017) The Impact of Dow Jones Sustainability Index on US Dollar Value, International Journal of Economics and Financial Issues, 7 (2), 556-561.

Maulinda, T. (2018). Pengaruh Harga Minyak Dunia, Nilai Tukar, Inflasi, Suku Bunga SBI, Indeks Dow Jones, dan Indeks Nikkei 225 terhadap Indeks Sektor Pertambangan yang Terdaftar Di Bursa Efek Indonesia (BEI) Periode 2011-2017. Jurnal Ilmu Manajemen (JIM), 6(3), 314-322.

Murti, W. (2017). The Impact of the Global Stock Market and the Foreign Exchange Market on Domestic Financial Market, European Research Studies Journal, 20, 99-111

Damayanti, A., Yulianti \& Rosyati. (2018). The Effect of Global Stock Price Index and Rupiah Exchange Rate on Indonesian Composite Stock Price Index (CSPI) in Indonesian Stock Exchange (IDX), Economics \& Business Solutions Journal, 2 (2), 4958.

Prawirosaputro, B., \& Hapsari, Y. D. (2017). The Effects Of Rupiah Currency, World Oil Prices, And World Gold Price On Composited Stock Price Index (IHSG) In 2016. Jurnal Manajemen, 14(2), 144-151

Rahman, M. \& Mustafa, M. (2018). Effects of Crude Oil and Gold Prices on US Stock Market for USA from ARDL Bounds Testing, Universe Scientific Publishing 
Al-Ameer, A., Hammad, W., Ismail, A. \& Hamdan, A. (2018). The Relationship of Gold Price with the Stock Market: The Case of Frankfurt Stock Exchange, International Journal of Economics and Financial Issues, 8 (5), 357-371.

Sa'adah, U., \& Suhadak. (2019). Pengaruh Makroekonomi Terhadap Kinerja Indeks Harga Saham Gabungan ( IHSG ) Dan Government Bonds ( Studi pada Negara Indonesia Tahun 2015-2017 ). 73(1), 151-159.

Seftarita, C., Fitriyani, Rizki, C.Z., Sapha, D. \& Jamal, A. (2019). Short Term Portfolio Investment and BI Rate, Journal of Economic Development, Environment and People, 8 (1), 2285-3642.

Robiyanto, Santoso, M.A., Atahau, A.D.R. \& Harijono. (2019). The Indonesia Stock Exchange and Its Dynamic, Montenegrin Journal of Economics, 15 (4), 59-73.

Tirto.id. 2019. Tahun Berat Pasar Modal: IHSG Cuma Tumbuh 1,7\% Sepanjang 2019 Tirto.ID. (https://tirto.id/tahun-berat-pasar-modal-ihsg-cuma-tumbuh-17-sepanjang2019-epSK. Diakses pada 9 Februari 2020). 